\title{
Components Separation Technique in Treatment of Patients with Ventral and Incisional Hernias (Review)
}

\author{
DOI: $10.17691 / \mathrm{stm} 2016.8 .1 .24$
}

Received August 26, 2014

\author{
V.V. Parshikov, MD, DSc., Professor, Department of Hospital Surgery named after B.A. Korolev'; Surgeon, \\ Anesthesiogist ${ }^{2}$ \\ V.I. Loginov, MD, PhD, Associate Professor, Surgeon ${ }^{3}$ \\ ${ }^{1}$ Nizhny Novgorod State Medical Academy, 10/1 Minin and Pozharsky Square, Nizhny Novgorod, 603005, \\ Russian Federation; \\ ${ }^{2}$ City Hospital No.35, 47 Respublikanskaya St., Nizhny Novgorod, 603089, Russian Federation; \\ ${ }^{3} 422$ Military Hospital, 25 Izhorskaya St., Nizhny Novgorod, 603105, Russian Federation
}

\begin{abstract}
There have been considered the failure origin of hernia repair in a certain group of patients with large ventral and incisional hernias. We have demonstrated why a number of current standard techniques cannot be successfully applied in these cases; and shown one of new and promising solutions of the problem. There have been considered the important aspects of an abdominal wall reconstruction with using the components separation technique (CST) in surgical management of ventral and incisional hernias according to data reported in foreign and Russian literature. A point of view of leading researchers on the indications for separation repair has been presented. CST methods are classified, their fundamental differences being shown. There have been described the technical aspects of performing an anterior and posterior separation, as well as the most interesting modifications significant for a surgeon.

The key points of the surgical techniques suggested by the method developers have been shown, and the existing CST modifications have been considered, their advantages and disadvantages being emphasized.

Special attention has been given to the technologies combining CST and prosthetic repair. We have assessed the role of these surgeries for the closure of large midline defects of an abdominal wall. There have been specified particular characteristics of surgical procedures depending on an approach, the structures of an abdominal wall to be separated, the mesh position in relation to the hernial orifice and anatomic abdominal wall layers, the transfer of self tissues.

We have specified the ways to solve a number of important problems in the management of patients with large ventral and incisional hernias with the abdominal cavity volume reduction.
\end{abstract} mesh.

Key words: components separation; incisional hernia; ventral hernia; prosthetic repair; tension-free plasty; abdominal wall repair; hernia;

Active implementation of abdominal wall prosthetic repair enables to improve significantly the treatment results of patients with ventral and incisional hernias, reduce a recurrence rate, and provide good life quality indicators of operated patients [1-3]. Tension-free repair has justly become the basis of modern herniology $[4,5]$. The main surgery types using synthetic endoprostheses have come to knowledge of a wide range of surgeons, and become an everyday practice $[6,7]$.

Despite the achieved success a recurrence rate following hernia repair still remains a problem for surgeons. A recurrence risk has been found to depend on a variety of factors including hereditary ones [810]. However, tension-free repair techniques rank first among the recurrence causes, the recurrence rate of an abdominal wall defect being in direct relationship with a hernia size $[3,11]$.

The surgical experience accumulation is certain to enable to exclude some technical mistakes and many errors in surgical approaches. However, currently, it is impossible to influence a number of specific pathogenic factors causing recurrent defects after prosthetic repair [12]. Some reasons existing still remain unresearched, while the others are under study. At the same time, a recurrence rate is well known to correlate with hernia orifice size and the herniation period [12]. Marked tension of abdominal wall tissues and high intraabdominal pressure (IAP) are also considered as one of the main causes of recurrence [13]. The tension results in cutting sutures that is prevented by synthetic material used, as well as due to the distribution of load on tissues, a reduced sewing effect of sutures [14].

However, there is a certain group of patients with incisional ventral hernias and abdominal cavity volume reduction [15]. According to meta-analysis data, the recurrence rate among these patients is maximal reaching $53 \%$ [16].

The problem is that repair surgeries in this group of patients are complex and traumatic, it relates to unacceptable complication rate, and even lethality [16-18]. As a result, some surgeons still use improved, author's autoplasty techniques even in the cases when

For contacts: Vladimir V. Parshikov, e-mail: pv1610@mail.ru 
the use of prosthetic technologies is obvious (e.g., in a patient with giant strangulated incisional hernia complicated by acute intestinal obstruction) [19]

Postoperative cardiovascular complications including venous thromboembolism are still unsolved problem [20, 21]. One of their triggers is intra-abdominal hypertension and hypercoagulation $[18,20,22]$. Specific regularity has been found by Russian researchers when stratifying patients by hernia orifice size and analyzing risk factors [23]. In patients operated using tension-free techniques the risk level was proportional to a hernia orifice size. Those undergone autoplasty appeared to have no such dependence. There was no mortality in W1-2 groups (according to Chevrel-Rath classification), while in W3-4 groups it was significantly lower compared to the patients operated by tension-free methods [23]. Therefore, tension-free repair principles should be observed perfectly in patients with large hernias $[24,25]$.

It should be admitted that classical approaches (sublay, onlay) do not suit to be used in the situations under consideration. When a great deal of hernia content enters the abdominal cavity, intra-abdominal hypertension can develop [26]. This syndrome is a complex of interrelated pathophysiological processes based on a marked (over $20 \mathrm{~mm} \mathrm{Hg}$ ) and continuous IAP increase associated with developing organ dysfunction [27]. It is allowable to use an inlay technique that enables to perform true tension-free repair [7, 28]. However, the technique does not imply the formation of an abdominal wall, which can function well, since it is followed by a postoperative diastasis recti abdominis. In case there is a part of abdominal content in a hernia, an inlay technique by a mesh can create and model an additional necessary volume of the abdominal cavity, and in this case the distance between the muscles mentioned is increasing. When in a pathological position, they suffer atrophy, and as time passes, there are changes in the operation zone: structure and metabolism of both muscular and connective tissues alter [29]. Chronic inflammation persisting on the periphery of an implanted endoprosthesis [30], a firm connective tissue frame does not form, and a muscular frame is getting more inadequate. Most recurrences develop within the first year after prosthetic repair [31] that is promoted by marked morphological changes of anterior abdominal wall tissues in patients with hernia detected by means of light optics and ultrasound [32]. According to other sources, 12 months after surgery there is a peak of recurrent hernia defects (33.3\%), and the formation period in $94.4 \%$ patients is up to 5 years [12]. The correlation of recurrences of onlay and inlay techniques with large-sized hernias and orifices, obesity, the period of hernia carrying for over 2 years, has been clearly demonstrated in the current studies [12]. Given these premises, it is clear why operative treatment of this group of patients (patients with large ventral and incisional hernias) using standard operative techniques does not always result in successful results [19, 33]. These patients should be treated differently.
Currently, there are relatively few techniques, which enable to approach the solution of the problems assigned. Any variant is based on the use of the separation technique of abdominal wall components (components separation technique - CST) located in its lower segment or laterally. Literature has descriptions of Ramirez, Maas, Ennis, Lindsey, Sukkar, Levine-Karp, Carbonell, Novitsky, etc. techniques [15, 34-39]. Neither Russian nor foreign literature presents a classification of techniques. Among available ones, there distinguished anterior components separation technique (ACST) and posterior components separation technique (PCST) including open and endoscopic surgeries.

Upon a closer consideration of surgical approach peculiarities, one can notice that sublay retromuscular technique does already contain some elements to mobilize abdominal wall components. The precise use of recommendation given by the researchers of this specified technique is an unconditional requirement, the negligence of the latter reduces to a minimum the advantages of the method. After typical procedures with hernia orifices and hernia content, a surgeon is to open sheath of rectus abdominis muscle [4] followed by the of retromuscular space dissection, separating step by step posterior surfaces of rectus abdominis muscles from the posterior sheath. The technique performed leads to the following: the posterior sheaths obtain unique mobility towards medialis (up to $6 \mathrm{~cm}$ ) that makes it possible to connect them tension-free during the following stage [40]. At a later stage, an endoprosthesis is placed on sutured posterior sheaths of rectus abdominis muscles, and fixed using tension-free technique, the mesh being subsequently placed retromuscularly $[4,40]$.

Nevertheless, in large-sized hernia orifices this procedure appears to be insufficient to close an abdominal wall defect with use the tension-free principles of tissue connection [40]. The problem becomes urgent in a large-sized hernial sac, when it contains some internal organs, the volume of the proper abdominal cavity being reduced.

Ramirez technique known since 1990 is a basic procedure for components separation (ACST) [2, 34-42]. This operation being an open ACST is a combination of techniques performed both in the middle, and the lateral segments. In addition, abdominal external oblique muscle aponeurosis is dissected $1.5-2 \mathrm{~cm}$ away from the line it attaches to the rectus abdominis muscle, and parallel to the latter along its entire length. Further, the tissues under aponeurosis are dissected laterally till lumbar veins appear. This technique is bilateral that enables to mobilize and replace the rectus abdominis muscles medially, the muscles being placed in their physiological position. The procedure enables to obtain extra mobility of abdominal wall layers $(4 \mathrm{~cm}$ in the upper abdomen, $8 \mathrm{~cm}$ in the umbilical area, and $3 \mathrm{~cm}$ in lower abdomen) [40]. Using this approach a surgeon gains approximately $15 \mathrm{~cm}$ in the middle segment of an abdominal wall transversally. According to other sources, the mobility is $5-10 \mathrm{~cm}, 10-15 \mathrm{~cm}$, and $3-8 \mathrm{~cm}$ in these abdominal areas, respectively [43]. 
A complex of the above mentioned techniques was called Ramirez 1 . The possibility to increase an abdominal cavity extent up to necessary and sufficient in cases of its initial reduction is an unquestionable advantage of the method, as it enables to place in situ hernia content causing no intra-abdominal hypertension [44]. The rectus abdominis muscles located in situ postoperatively start functioning well preventing recurrences $[45,46]$. Initial incompetence of the mentioned muscles or their damage is not the contradiction for the described surgical approaches [47].

Perfect execution of all the mentioned stages for large defect closure is of importance since every stage successively increases tissue mobility in a medial segment $[48,49]$.

The results of Ramirez techniques for large incisional hernias appeared to be rather promising, and differed drastically from traditional repair techniques using local tissues [34, 35]. They prove demonstratively to be purely comparable with those after mesh prosthetic repair [38]. Some authors until recently have considered the technique as a method of choice in some situations and a real alternative to prosthetic repair [50].

The apparent limitations of Ramirez technique are the scope of surgery, significant area of tissue dissection, large wound surface both in dense abdominal wall layers, and in the zone of subcutaneous flap separation. The authors studying the causes of hernia recurrences emphasize that certain principles should be followed carefully: anatomy specificity, no traumas, biological aspect, physiological aspect, functionality [51]. Some authors correctly reason Ramirez technique to be contrary to some of these principles [51]. On the other side, it is very important to close abdominal wall defects using not only synthetic material, aponeurosis but also muscles. Scientists possessing knowledge of such operations specify that CST requires thorough hemostasis and adequate drainage of surgical area to prevent the formation of liquid accumulations and local complications [38]. CST does not raise the risk of venous thromboembolic complications [52]. Due to significant tissue separation, there is always the risk of skin necrosis in a median abdominal wall segment [53]. This is due to the fact that the blood supply of a cutaneoussubcutaneous flap in a medial segment is provided by epigastric arteries through perforated vessels, which are ligated or coagulated in the course of Ramirez operation [54]. The same reasons (local circulation impairments) underlie a long-term exudation and liquid accumulation formation in the area a cutaneous-subcutaneous flap is separated from subjacent tissues [55]. An alternative has been brought forward, it saving perforated vessels in paraumbilical area that enables to preserve circulation to a certain extent, and avoid local ischemic complications [56]. Some surgeons perform precision removal of subscarpal fat layer as well. Similar methods are used in lipoabdominoplasty in hernia carriers [57]. Intra-operative angiographic technologies are known to be applied to check the boundaries of adequate perfusion [58].
The other widespread problem of treatment of patients with hernias is the abdominal wall weakening lateral to rectus abdominis muscles [59]. In some cases, abdominal wall deformity areas can develop by relaxation or hernia type [59]. If a subcutaneous fat layer is poorly marked it can have a good cosmetic effect. These changes have clear anatomical and pathophysiological conditions. After Ramirez operation, an abdominal wall in the zones situated lateral to rectus abdominis muscles does not comprise aponeurosis of abdominal external oblique muscle. Moreover, the latter loses its medial attachment points and can become functionally inadequate, replaces laterally, and will be in contracture condition.

Other alternatives to Ramirez operation have been suggested later, they being developed to overcome the drawbacks mentioned above. In some cases CST safety can be insufficient. First of all it concerns large incisional hernias with significant abdominal cavity reduction, other risk factors being of importance as well. The idea to combine the advantages of prosthetic repair and CST seems to be an interesting approach to solve the problem [35, 44, 53,60]. After providing an access and the necessary procedures in the abdominal cavity according to CST stage, prosthetic repair is performed a medial segment of the abdominal wall $[56,60]$.

Another method of CST (Ramirez 2) differs from a classical Ramirez operation in the following: it predisposes mesh prosthetic repair of both medial segment, and the abdominal wall components separation zone lateral to rectus abdominis muscles. In addition, semilunar-shaped endoprostheses are used in lateral parts. A medial margin of such implant is fixed to the inner edge of a dissected aponeurosis of abdominal external oblique muscle. A lateral (semi-elliptic) margin is placed between external and internal oblique muscles, while a lateral margin of the dissected aponeurosis of external oblique muscle is attached tension-free to a mesh at its location. A surgeon performs the same procedures contralaterally. As a result, all trouble parts of the abdominal cavity appear to be closed, and external oblique muscles again have the attachment points, and subsequently will function adequately [61]. The drawbacks of this variant of Ramirez operation are to be considered: significant load by synthetic material, the vastitude of prosthetic area, the presence of a contact between a mesh and cubcutaneous tissue (as in onlay repair). Other authors [62] instead of two meshes in lateral segments use one, which is attached to the lateral margins of an aponeurosis of external oblique muscles, the technique was described in 2011. Moreover, there have been described the methods combining CST and onlay, inlay, sublay and sublay-onlay techniques [40, $45,53,61,63,64]$. There is an "open book" technique. The aponeurosis of the external oblique muscle and the anterior sheath of rectus abdominis muscle is cut by an incision; the posterior one being rotated abdominally and medially in order to be used for direct closure of a tissue defect in a medial abdominal wall segment [65] as in V.I. Belokonev technique [66]. Other authors apply 
similar methods [67]. There are simplified CST versions based on a basic technique [68].

The findings of combined usage of prosthetic repair and ACST require further investigations related to a relatively little experience of clinics. The remarkable fact is that sometimes there can be observed the regularities typical for the use of prosthetic repair alone. For instance, the series onlay + CST are found to have far more numbers of wound complications compared to IPOM + CST [69]. Both synthetic and biological materials are known to be applied for abdominal wall defect closure concurrently with components separation [70].

ACST is successfully combined with autoplasty in a medial abdominal wall segment [46]. The studies based on large material clearly demonstrated CST to be successfully combined with autodermoplasty, and a skin graft can be placed both in a medial abdominal wall segment as well as laterally (in the dissection area of obliquus externus abdominis aponeurosis) $[46,54]$. Abdominal rectus muscles have been shown to repair their functional activity after such operation [45]. The same researchers emphasize that there is no rehabilitation mentioned in case of the combination of Ramirez operation and total prosthetic repair of an abdominal wall using onlay technique [71].

ACST can be performed endoscopically, and it is written in the guidelines of International Endohernia Society $[72,73]$. This technique was suggested by Maas and described in detail by Clarke [74]. Minimally invasive CST techniques are implemented by foreign and Russian surgeons [53, 75-78]. It enables to reduce significantly wound complication rate from 57 to $19 \%$ [76]. There has been demonstrated the capability to combine the technique with one of prosthetic repair methods, both open and laparoscopic (IPOM, onlay, sublay retromuscular, preperitoneal) [72]. Moreover, only a medial segment is strengthen by a mesh, no implantation being performed in the area of obliquus externus abdominis aponeurosis. The volume of tissues dissected in a lateral segment and therefore the intended mobility of a medial segment of an anterior abdominal wall is considered to be higher compared to those after Ramirez operation, though the infection rate of a surgical intervention area and the problems with wound healing is lower in endoscopic CST [73]. Laparoscopic separation is successfully used in large inguinal hernias with an abdominal volume reduction [79].

The experience of performing the mentioned anterior separations gain by surgeons in Russian clinics is still relatively rich, though the interest of herniology community to the specified techniques tends to increase steadily $[53,80]$. Ramirez technique in one form or another was present in 1 study (2011), 5 publications (2012), and in 3 manuscripts according to the materials of All-Russia herniology conference, Moscow. According to online query (2012), most hernilogists have not had the experience of such operations [81]. The same source mentioned the opinion of $44.9 \%$ surgeons, who think that CST should replace inlay technique.

PCST is known as the variant of abdominal wall components separation technique, which presupposes the retention of obliquus externus abdominis aponeurosis, while transversus abdominis (and occasionally, internal oblique) muscle is separated from rectus abdominis muscles bilaterally. As a rule, CST is combined with one of prosthetic repair techniques.

There are different, and in some cases, controversial views on the effect the described CST methods have on anatomical functional properties of the forming abdominal cavity. It should be noted that nerve trunks providing functional activity of rectus abdominis muscles are between the internal oblique and transverse muscles [38], therefore anterior separation in its typical performance does not imply any contact with the mentioned nerve trunks. Posterior separation requires particular tissue dissection at a certain stage as technical drawbacks can result in adromia. And it is a rather aspect of this technique requiring further investigations.

The term PCST and posterior separation technique combined with retromuscular repair were suggested by Carbonell et al. in 2008 [36]. The authors recommend performing typical dissection of retromuscular space, dissect vertically the posterior leaf of sheath of rectus abdominis muscle followed by tissue preparation laterally between the transverse and internal oblique abdominal muscles. The defined cavity of tissue separation are further used to place a synthetic endoprosthesis, which is rather large, and it will be situated in a medial abdominal wall segment, dorsal to rectus abdominis muscles, and in a lateral segment internal oblique muscles. The mesh edges are fixed to tissue using transaponeurotic sutures [36].

Another technique of posterior separation was elaborated by Novitsky et al. and described as TAR (transversus abdominis muscle release) operation [37]. The separation of muscular aponeurotic abdominal wall structures is advised to start with retromuscular space dissection described above. After completing the area preparation, a surgeon should clearly visualize epigastral and perforating vessels just near the semilunar line. The posterior leaf of sheath of rectus abdominis muscle is dissected vertically, $0.5-1.0 \mathrm{~cm}$ medial to its lateral margin, the transverse muscle being visualized and vertically dissected throughout its length. Then the tissues are dissected laterally between the transverse and internal oblique muscles resulted in a significant increase of mobility of all the tissue complex of medial abdominal wall segment, and mainly its substructures: the posterior leaves of sheath of rectus abdominis muscles and the transverse fascia. The authors advise their suturing along the midline, a synthetic endoprosthesis being placed on the latter ones, and fixed around the periphery by transaponeurotic sutures [37]. Posterior separation is also known [82] to be completed by both retromuscular, and intra-abdominal plasty as well. The combination of open posterior separation and prosthetic repair is associated with good functional results that have been demonstrated in some other works [83]. 
A postoperative period is known to develop hypertrophy of rectus and oblique abdominis muscles and atrophy of transverse muscles [84]. Similar data have been shown compared to posterior separation with bridging technique in laparoscopic variant, the muscles remaining reliably unaltered. American researchers, when comparing the results of anterior (Ramirez) and posterior (TAR) separations, found the following. The first variant appeared to have significantly more wound complications, while the recurrence rate had no significant differences [85, 86]. In general, researchers highly appreciate the capabilities of different abdominal wall separation techniques [87].

Russian surgeons have suggested a combined abdominal repair technique for large incisional hernias, the technique being a PCST type combined with retromuscular prosthetic repair [88]. After retromuscular space dissection the authors recommend having the tendon part of the internal oblique and transverse abdominal muscles dissected, and the endoprosthesis is fixed to the tendon part of the external oblique muscle. No skin-subcutaneous flap detachment can be regarded the advantage of the described technique. The inventors do not specify in the patent how blood supply and innervations of rectus abdominis muscle changes. Many other scientists correctly reason that arterial blood flow can be sufficient due to epigastric vessels, the innervations in this case being inevitable. Nevertheless, there is a technique combining prosthetic repair and CST, this technique is difficult to classify since the authors after separating the anterior leaf of sheath of rectus abdominis muscles from the latter ones perform the dissection of a tendon part of these muscles [89]. No wide detachment of subcutaneous tissue from underlying tissues is referred to as the advantage of the method, and the drawback is evident adromia of rectus abdominis muscles. The same authors have described a combined plasty based on the combination of components separation and mesh implantation [90]. The authors recommend using pararectal approaches performing the dissection of a tendon part of the external oblique, internal oblique and transverse abdominal muscles followed by replacing the area (a lateral segment) by a mesh using inlay technique, and medial segment by an onlay mesh.

Positive results of applying an original CST variant combining the elements of anterior separation on one side, and posterior separation contralaterally combined with a modified sublay technique. It enabled the authors to close large abdominal wall defects successfully. Posterior separation technique is being mastered in the overwhelming majority of Russian clinics, however, it has spread abroad [36, 82]. Some clinics in the USA successfully use a laparoscopic variant of the technique [91]. Foreign studies have compared the results and the cost of an open and laparoscopic separation technique. Total financial expenses when performing endoscopic CST are shown to be lower, though the differences are not significant at inpatient stage. Wound complication rate in open separation technique is higher, the data on differences being insignificant either [92]. Metaanalyses carried out by 2014 have clearly shown that the implementation of endoscopic separation contributes to a significant decrease of wound complication rate (infection in the surgical intervention area, dihescence, skin necrosis, celluilitis) compared to an open technique [93]. The following is noteworthy: there have been compared open and minimally invasive surgeries including the use of abdominal wall components separation techniques without differentiation into anterior and posterior separation. It was important for correct data comparison provided that more laparoscopic operations are being performed in the USA, with posterior separation being given preferences compared to West Europe. In recent years there have been reports on total laparoscopic abdominal wall (adhesiolysis, the rectus abdominis muscles are displaced to physiological position, IPOM and ACST), though the authors are not satisfied with the results [94, 95].

The variants of techniques mentioned make it possible for surgeons to choose an appropriate method in ventral and incisional hernias, therefore, currently, a repair of hernia defects of any size and localizations is technically feasible. However, to the present day, the problem of applicability of the mentioned repair techniques is still unresolved in certain situations. Some authors believe CST and prosthetic repair results to be quite comparable, and find no significant differences concerning wound infection, recurrences and life quality parameters [96]. Drug CST has also been described [97].

The application of modern abdominal wall components separation technique is certain to make it possible to perform repairs rather than corrections in the majority of cases, even in large defects. In giant hernias, in case of abdominal cavity reduction, the suggested technique can be a safe and adequate approach, being actually a method of choice. The combination of prosthetic repair and CST in large hernias has been brought out clearly to be significantly safer than the use of tension-free technique using a mesh (bridging technique) [98]. Less complications and recurrences are observed. Anterior separation technique has a number of advantages over inlay technique, and is consistent with a concept of an adequate abdominal wall repair in large hernias, therefore, it can be recommended for people of workable age.

On the other hand, it is not clear if there is sense in performing such a complex and large-scale surgeries in a problem group of patients: elderly patients, patients with some comorbidities, as well as in emergency hernia surgery. Some publications report about successful application of CST and/or prosthetic repair in elderly patients (in the presence of infectious complications), as well as in cases of injuries and an acute open postoperative abdominal wall syndrome [99-103]. Components separation technique is frequently used if surgical treatment of ventral or incisional hernias includes the removal of an apron of fat tissue [104].

Current meta-analyses have clearly demonstrated 
a number of regularities. Patients with abdominal wall hernias present a very heterogeneous group. Prosthetic repair should always be used in patients with large abdominal wall hernias. Sublay technique is preferable, and if is necessary for the operation to be tensionfree, it can be completed by CST [16]. In some cases computed tomography findings help specify indications for any given operation [105, 106]. Modern authors consider a combination of sublay or other techniques with CST to be a method of choice for large-sized defects [107-112].

Thus, separation repair of an abdominal wall is a safe and effective technology, and should be included in the technique of any surgeon who operates patients with large ventral and incisional hernias.

However, some aspects of surgical technique require development; a detailed study of immediate and longterm results of the operation is needed; life quality parameters of the operated patients compared to other surgical repair techniques of abdominal wall defects are to be analyzed.

Study Funding and Conflicts of Interest. The study was not funded by any sources, and the authors have no conflicts of interest related to the present study.

\section{References}

1. Andersen L.P.H., Klein M., Gögenur I., Rosenberg J. Long-term recurrence and complication rates after incisional hernia repair with the open onlay technique. BMC Surg 2009; 9: 6, http://dx.doi.org/10.1186/1471-2482-9-6.

2. Kingsnorth A.N. The management of incisional hernia. Ann $R$ Coll Surg Engl 2006; 88(3): 252-260, http://dx.doi.org/ 10.1308/003588406X106324.

3. Yurasov A.V., Abovyan L.A., Kurashvili D.N., Lysenko M.V., Dubrov V.E. Distant results of surgical treatment in patients with umbilical hernia and diastasis recti. Vestnik eksperimental'noy i klinicheskoy khirurgii 2014; 4(7): 309-314.

4. Rezolyutsiya $X$ nauchnoy konferentsii "Aktual'nye voprosy gerniologii" [Resolution of $\mathrm{X}$ scientific conference "Urgent problems of herniology"]. Moscow; 2013. URL: http:// herniaweb.ru/index.php?cat_id=30.

5. Samsonov A.A. Atenzionnaya alloplastika $v$ khirurgicheskom lechenii ushchemlennykh gryzh peredney bryushnoy stenki. Avtoref. dis. ... kand. med. nauk [Tensionfree alloplasty in surgical treatment of anterior abdominal wall strangulated hernias. PhD Thesis]. Nizhny Novgorod; 2009.

6. Korenkov M., Paul A., Sauerland S., Neugebauer E., Arndt M., Chevrel J.P., Corcione F., Fingerhut A., Flament J.B., Kux M., Matzinger A., Myrvold C.E., Rath A.M., Simmermacher R.K.J. Classification and surgical treatment of incisional hernia. Langenbeck's Arch Surg 2001; 386(1): 65-73, http://dx.doi.org/10.1007/s004230000182.

7. Baulin A.V., Baulin V.A., Khytin A.N. Hernioplasty through district hospital surgeon's eyes. Byulleten' meditsinskikh Internet-konferentsiy 2013; 3(8): 1045-1048.

8. Bart I.I., Ivanov V.P., Ivanov S.V., Trubnikova E.V. Transforming growth factor in a case of abdominal hernia. Sovremennye problemy nauki i obrazovaniya 2013; 1. URL: http://www.science-education.ru/pdf/2013/1/67.pdf.

9. Bart I.I., Ivanov V.P., Ivanov S.V., Trubnikova E.V. Matrix metalloproteinase polymorphisms and its involvement into incisional hernia development at person. Nauchnye vedomosti Belgorodskogo gosudarstvennogo universiteta. Seriya: Meditsina. Farmatsiya 2013; 4(147): 156-160.

10. Ivanov S.V., Goryainova G.N., Tarabrin D.V. Analysis of the ratio of collagen types I and III in skin and aponeurosis in patients with ventral hernias. Vestnik eksperimental'noy $i$ klinicheskoy khirurgii 2013; 3: 331-334.

11. Yurasov A.V., Shestakov A.L., Kurashvili D.N., Abovyan L.A. The modern concept of surgical treatment of patients with postoperative hernias of the anterior abdominal wall. Vestnik eksperimental'noy i klinicheskoy khirurgii 2014; 4(7): 405-413.

12. Upyrev A.V., Khmel'nitskiy A.l., Volokitin A.S., Molozina E.L., Droganova T.A., Kal'naya N.A., Platonova G.A. Retsidiv posleoperatsionnoy gryzhi v protezirovannoy bryushnoy stenke: mekhanizm i sroki vozniknoveniya, dokazatel'naya baza, klassifikatsionnyy podkhod. V kn.: Materialy IX konferentsii "Aktual'nye voprosy gerniologii" [An incisional hernia recurrence in replaced abdominal wall: mechanism and occurrence, evidentiary basis, classificatory approach. In: Proceedings of IX conference "Urgent problems of herniology"]. Moscow; 2012; $p$. 202-204.

13. Charyshkin A.L., Frolov A.A. Assessment of quality of life at patients after hernioplasty big and huge postoperative the ventral of hernias. Sovremennye problemy nauki i obrazovaniya 2013; 5. URL: http://www.science-education.ru/111-10622.

14. Bushuev V.V., Ovchinnikov V.A., Tishkova S.K., Kudryavtsev A.P. Sposob zakrytiya gryzhevykh defektov $i$ ukrepleniya myshechno-aponevroticheskogo sloya peredney bryushnoy stenki [A way to close hernial defects and reinforce muscular aponeurotic layer of an anterior abdominal wall]. Patent RF 2314042. 2008.

15. Ponomareva Y.V., Belokonev V.I., Volova L.T., Gulyaev M.G. The morphological basis of the causes of recurrence in patients with postoperative ventral hernias. Fundamentalnie issledovania 2013; 9(part 2): 263-266.

16. Eriksson A., Rosenberg J., Bisgaard T. Surgical treatment for giant incisional hernia: a qualitative systematic review. Hernia 2014; 18(1): 31-38, http://dx.doi.org/10.1007/s10029-0131066-y.

17. Gorpinich A.B. The results of postoperative ventral hernia operative treatment. Uchenye zapiski Orlovskogo gosudarstvennogo universiteta. Seriya: Estestvennye, tekhnicheskie i meditsinskie nauki 2013; 6(56): 207-209.

18. Pleshkov V.G., Agafonov O.I. Incisional ventral hernias unsettled questions. Vestnik eksperimental'noy $i$ klinicheskoy khirurgii 2009; 3: 248-255.

19. Karapysh D.V. Giant incisional hernias, complicated by acute ileus as the most difficult issue of urgent surgery and the ways of its solution. Vestnik novykh meditsinskikh tekhnologiy 2013; 3: 88-91.

20. Tsverov I.A., Bazaev A.V. The correction of blood coagulation defects for the purpose of complications prevention in surgical treatment of postoperative ventral hernias. Sovremennye tehnologii v medicine 2011; 2: 155-158.

21. Pannucci C.J., Basta M.N., Fischer J.P., Kovach S.J. Creation and validation of a condition-specific venous thromboembolism risk assessment tool for ventral hernia repair. Surgery 2015; 158(5): 1304-1313, http://dx.doi. org/10.1016/j.surg.2015.04.001.

22. Klokov V.A., Khorev A.N., Kozlov S.V. Hypercoagulation in patients after herniotomy with mesh prosthesis explantation. Vrach-aspirant 2012; 2.3(51): 400-404. 
23. Pushkin S.Yu., Belokonev V.I., Reshetov A.P., Aksenova E.V., Dolgikh E.S. Evaluation of complications in patients with hernias, depending on the degree of operational risk and severity of injury. Tol'yattinskiy meditsinskiy konsilium 2011; 3-4: 154-157.

24. Golovin R.V., Nikitin N.A., Prokopiev A.A. Prognosis of development of complications of injuries after combined allohernia plastic interventions for postoperative ventral hernias of median localisation. Sovremennye problemy nauki i obrazovaniya 2014; 2. URL: http://www.science-education.ru/pdf/2014/ 2/644.pdf.

25. Nikitin N.A., Goloviznin A.A., Golovin R.V. Choice of the method of combined alloherinia plastic interventions in postoperative ventral hernias of median localisations. Fundamentalnie issledovania 2014; 4-3: 572-577. URL: http:// www.rae.ru/fs/?section $=$ content $\& o p=$ show_article \&article_ id $=10003231$.

26. Musaev A.I., Toktogulov O.Zh. Selection criteria of a plasty extent in large and giant incisional ventral hernias. Vestnik KGMA im. I.K. Akhunbaeva 2013; 4: 75-77.

27. Ovchinnikov V.A., Sokolov V.A. Abdominal compartment syndrome. Sovremennye tehnologii $v$ medicine 2013; 5(1): 122-129.

28. Klokov V.A. The significance of "tension-free" repair of hernia effect in thromboembolic event prevention in patients with incisional ventral hernias. Sibirskiy meditsinskiy zhurnal (Irkutsk) 2012; 2: 20-22.

29. Grigoryuk A.A. The structure of aponeurosis the anterior abdominal wall rights in norm and pathology. Vestnik novykh meditsinskikh tekhnologiy 2011; 2: 104-106.

30. Belokonev V.I., Fedorina T.A., Pushkin S.Yu., Nagapetyan S.V. Morphological substantiation of biomechanical concept of ventral hernia pathogenesis. Morfologicheskie vedomosti 2009; 3(part 4): 121-124.

31. Dambaev G.Ts., Khokhlov K.S., Gabidulina N.V., Shcheglov A.V. Reconstructive surgery in patients with postoperative ventral hernia. Sibirskiy meditsinskiy zhurnal (Tomsk) 2011; 2(part 1): 121-124.

32. Andryushchenko V.P., Kushnirchuk N.I. Micro- and ultrastructural changes of the anterior abdominal wall tissues as a principle of selection of a hernioplasty technique in incisional ventral hernias. Astrakhanskiy meditsinskiy zhurnal 2012; 4: $18-21$.

33. Botezatu A.A. Vybor metoda plastiki bol'shikh i gigantskikh posleoperatsionnykh, retsidivnykh sredinnykh gryzh zhivota. V kn.: Materialy X nauchnoy konferentsii "Aktual'nye voprosy gerniologii" [The choice plastic repair techniques of large and giant incisional median abdominal recurrent hernias. In: Proceeding of $X$ scientific conference "Urgent problems of herniology"]. Moscow; 2013; p. 28-30.

34. Ramirez O.M., Ruas E., Dellon A.L. "Components separation" method for closure of abdominal-wall defects: an anatomic and clinical study. Plast Reconstr Surg 1990; 86(3): 519-526, http://dx.doi.org/10.1097/00006534-19900900000023.

35. Heller L., McNichols C.H., Ramirez O.M. Component separations. Semin Plast Surg 2012; 26(1): 25-28, http://dx.doi. org/10.1055/s-0032-1302462.

36. Carbonell A.M., Cobb W.S., Chen S.M. Posterior components separation during retromuscular hernia repair. Hernia 2008; 12(4): 359-362, http://dx.doi.org/10.1007/s10029008-0356-2.

37. Novitsky Y.W., Elliott H.L., Orenstein S.B., Rosen M.J. Transversus abdominis muscle release: a novel approach to posterior component separation during complex abdominal wall reconstruction. Am J Surg 2012; 204(5): 709-716, http://dx.doi. org/10.1016/j.amjsurg.2012.02.008.

38. de Vries Reilingh T.S. Reconstruction of large abdominal wall defects: 'components separation technique' and prosthetic repair. Gildeprint BV, Enschede, The Netherlands; 2007.

39. Ennis L.S., Young J.S., Gampper T.J., Drake D.B. The "open-book" variation of component separation for repair of massive midline abdominal wall hernia. Am Surg 2003; 69(9): 733-742.

40. Bogetti P., Boriani F., Gravante G., Milanese A., Ferrando P.M., Baglioni E. A retrospective study on mesh repair alone vs. mesh repair plus pedicle flap for large incisional hernias. Eur Rev Med Pharmacol Sci 2012; 16(13): 1847-1852.

41. Bleichrodt R.P., de Vries Reilingh T.S., Malyar A., van Goor H., Hansson B., van der Kolk B. Component separation technique to repair large midline hernias. Operative Techniques in General Surgery 2004; 3(6): 179-188, http:// dx.doi.org/10.1053/j.optechgensurg.2004.07.001.

42. Kingsnorth A.N. Hernia surgery: from guidelines to clinical practice. Ann R Coll Surg Engl 2009; 91(4): 273-279, http://dx.doi.org/10.1308/003588409X428540.

43. Shell D.H., de la Torre J., Andrades P., Vasconez L.O. Open repair of ventral incisional hernias. Surg Clin North $A m$ 2008; 88: 61-83, http://dx.doi.org/10.1016/j.suc.2007.10.008.

44. Vlasov V.V., Kalinovskiy A.V. K lecheniyu pupochnoy gryzhi gigantskikh razmerov. V kn.: Materialy IX konferentsii "Aktual'nye voprosy gerniologii" [About treatment of giant umbilical hernias. In: Proceedings of IX conference "Urgent problems of herniology"]. Moscow; 2012; p. 55-57.

45. Raylyanu R.I., Botezatu A.A., Kovalenko T.N. Izuchenie funktsii myshts peredney bryushnoy stenki u bol'nykh $\mathrm{s}$ posleoperatsionnymi sredinnymi gryzhami. V kn.: Materialy IX konferentsii "Aktual'nye voprosy gerniologii" [The study of functions of the anterior abdominal wall muscles in patients with incisional median hernias. In: Proceedings of IX conference "Urgent problems of herniology"]. Moscow; 2012; p. 176-178.

46. Botezatu A.A., Raylyanu R.I., Eval'd A.M. Rezul'taty lecheniya gryzh peredney bryushnoy stenki kombinirovannymi sposobami gernioplastiki. V kn.: Materialy VII konferentsii "Aktual'nye voprosy gerniologii" [Treatment results of anterior abdominal wall hernias by combined hernioplasty techniques. In: Proceedings of VIII conference "Urgent problems of herniology"]. Moscow; 2011; p. 39-41.

47. Garvey P.B., Bailey C.M., Baumann D.P., Liu J., Butler C.E. Violation of the rectus complex is not a contraindication to component separation for abdominal wall reconstruction. J Am Coll Surg 2012; 214(2): 131-139, http:// dx.doi.org/10.1016/j.jamcollsurg.2011.10.015.

48. Barbosa M.V., Nahas F.X., de Oliveira Filho R.S., Ayaviri N.A., Novo N.F., Ferreira L.M. A variation in the component separation technique that preserves linea semilunaris: a study in cadavers and a clinical case. J Plast Reconstr Aesthet Surg 2010; 63(3): 524-531, http://dx.doi. org/10.1016/j.bjps.2008.12.008.

49. Barbosa M.V., Ayaviri N.A., Nahas F.X., Juliano Y., Ferreira L.M. Improving tension decrease in components separation technique. Hernia 2014; 18(1): 123-129, http:// dx.doi.org/10.1007/s10029-013-1094-7.

50. Kim Z., Kim Y.J. Components separation technique for large abdominal wall defect. J Korean Surg Soc 2011; 80(Suppl 1): S63-S66, http://dx.doi.org/10.4174/jkss.2011.80.Suppl1.S63.

51. Fedoseev A.V., Murav'ev S.Yu. Osnovnye printsipy 
bezretsidivnoy khirurgii gryzh. V kn.: Materialy IX konferentsii "Aktual'nye voprosy gerniologii" [Basic principles of recurrencefree hernia surgery. In: Proceedings of VIII conference "Urgent problems of herniology"]. Moscow; 2011; p. 206-208.

52. Kim K., Mella J.R., Ibrahim A.M., Koolen P.G., Lin S.J. Is there an association between component separation and venous thromboembolism? Analysis of the NSQIP. Plast Reconstr Surg Glob Open 2015; 3(6): e429, http://dx.doi.org/10.1097/ GOX.0000000000000167.

53. Darvin V.V., Barbashinov N.A., Bubovich E.V. Osobennosti khirurgicheskoy taktiki u bol'nykh $\mathrm{s}$ bol'shimi i gigantskimi posleoperatsionnymi gryzhami. V kn.: Materialy IX nauchnoy konferentsii "Aktual'nye voprosy gerniologii" [Peculiarities of surgical approach in patients with large and giant incisional hernias. In: Proceedings of IX conference "Urgent problems of herniology"]. Moscow; 2012; p. 69-71.

54. Botezatu A.A., Raylyanu R.I. Abdominoplasty in herniotomy of large and giant recurrent median hernias. Moskovskiy khirurgicheskiy zhurnal 2011; 6(22): 14-17.

55. Pushkin S.Yu., Belokonev V.I., Shifrin G.I., Larina T.V., Klyuev K.E., Kuznetsov O.E. The nature of morphofunctional changes in tissues in the formation of liquid masses in subcutaneous tissue in patients after herniotomy. Novosti khirurgii 2011; 19(2): 16-20.

56. Heller L., Chike-Obi C., Xue A.S. Abdominal wall reconstruction with mesh and components separation. Semin Plast Surg 2012; 26(1): 29-35, http://dx.doi.org/10.1055/s-00321302463.

57. Ivanov V.V., Yudin V.A. Surgical methods of increasing safety and effectiveness of lipoabdominoplasty performance in patients with ventral hernias. Vestnik Natsional'nogo medikokhirurgicheskogo tsentra im. N.I. Pirogova 2011; 3: 32-37.

58. Wang H.D., Singh D.P. The use of indocyanine green angiography to prevent wound complications in ventral hernia repair with open components separation technique. Hernia 2013; 17(3): 397-402, http://dx.doi.org/10.1007/s10029-012-0935-0.

59. Botezatu A.A. Abdominal wall reconstruction at the hernioplasty of the big and huge, recurrent median hernias. Vestnik Rossiyskogo universiteta druzhby narodov. Seriya: Meditsina 2013; 1: 58-63.

60. Shestak K.C., Edington H.J., Johnson R.R. The separation of anatomic components technique for the reconstruction of massive midline abdominal wall defects: anatomy, surgical technique, applications, and limitations revisited. Plast Reconstr Surg 2000; 105(2): 731-739, http:// dx.doi.org/10.1097/00006534-200002000-00041.

61. Nockolds C.L., Hodde J.P., Rooney P.S. Abdominal wall reconstruction with components separation and mesh reinforcement in complex hernia repair. BMC Surgery 2014, 14: 25, http://dx.doi.org/10.1186/1471-2482-14-25.

62. Bröker M., Verdaasdonk E., Karsten T. Components separation technique combined with a double-mesh repair for large midline incisional hernia repair. World J Surg 2011; 35(11): 2399-402, http://dx.doi.org/10.1007/s00268-011-1249-6.

63. Hood K., Millikan K., Pittman T., Zelhart M., Secemsky B., Rajan M., Myers J., Luu M. Abdominal wall reconstruction: a case series of ventral hernia repair using the component separation technique with biologic mesh. Am J Surg 2013; 205(3): 322328, http://dx.doi.org/10.1016/j.amjsurg.2012.10.024.

64. Siddique K., Shrestha A., Basu S. Multi-staged repair of contaminated primary and recurrent giant incisional herniae in the same hospital admission: a proposal for a new approach. Hernia 2014; 18(1): 57-63, http://dx.doi.org/10.1007/s10029-013-1051-5.
65. Mericli A.F., Bell D., DeGeorge B.R. Jr., Drake D.B. The single fascial incision modification of the "open-book" component separation repair: a 15-year experience. Ann Plast Surg 2013; 71(2): 203-208, http://dx.doi.org/10.1097/ SAP.0b013e31829565ba.

66. Pushkin S.Yu., Belokonev V.I. Treatment of medial ventral hernias with the use of synthetic endoprosthesis. Khirurgiia. Zhurnal im. N.I. Pirogova 2010; 6: 43-45.

67. Takahashi M., Nishida S., Panthaki Z.J., Fan J., Romano A., Tekin A., Island E.R., Moon J.I., Levi D.M., Tzakis A.G. Use of the bilateral anterior rectus fascia turnover method and the components separation method for a difficult abdominal closure after transplantation. Liver Transpl 2012; 18(9): 1121-1123, http://dx.doi.org/10.1002/lt.23486.

68. Celdrán-Uriarte A., Fraile M., García-Vasquez C., York E., Manso B., Granizo J.J. A simplified incision of the external oblique aponeurosis during the components separation technique for the repair of large incisional hernias. Am J Surg 2011; 202(3): e31-e33, http://dx.doi.org/10.1016/ j.amjsurg.2010.08.039.

69. Feleshtinskiy Ya.P., Smishchuk V.V., Yosipenko M.A. Ramirez's technique combined with intraperitoneal alloplasty in giant postoperative abdominal hernias. Khirurgiya. Vostochnaya Evropa 2015; 4(16): 137-143.

70. Alicuben E.T., DeMeester S.R. Onlay ventral hernia repairs using porcine non-cross-linked dermal biologic mesh. Hernia 2014; 18(5): 705-712, http://dx.doi.org/10.1007/s10029013-1054-2.

71. Raylyanu R.I., Botezatu A.A., Kovalenko T.N., Burlak V.A., Karaman L.A. Vosstanovlenie funktsiy myshts zhivota posle rekonstruktivnoy gernioplastiki. $\mathrm{V}$ kn.: Materialy $X$ nauchnoy konferentsii "Aktual'nye voprosy gerniologii" [Functional recovery of abdominal muscles after reconstructive hernioplasty. In: Materials of $\mathrm{X}$ scientific conference "Urgent problems of herniology"]. Moscow; 2013; p. 130-132.

72. Bittner R., Bingener-Casey J., Dietz U., Fabian M., Ferzl I.G., Fortelny R., et al. Guidelines for laparoscopic treatment of ventral and incisional abdominal wall hernias (International Endohernia Society [IEHS]) - part III. Surg Endosc 2014; 28(2): 380-404, http://dx.doi.org/10.1007/s00464-013-3172-4.

73. Vorst A.L., Kaoutzanis C., Carbonell A.M., Franz M.G. Evolution and advances in laparoscopic ventral and incisional hernia repair. World J Gastrointest Surg 2015; 7(11): 293-305, http://dx.doi.org/10.4240/wjgs.v7.i11.293.

74. Clarke J.M. Incisional hernia repair by fascial component separation: results in 128 cases and evolution of technique. Am Surg 2010; 200(1): 2-8, http://dx.doi.org/10.1016/ j.amjsurg.2009.07.029.

75. Ghali S., Turza K.C., Baumann D.P., Butler C.E. Minimally invasive component separation results in fewer wound-healing complications than open component separation for large ventral hernia repairs. J Am Coll Surg 2012; 214(6): 981-989, http:// dx.doi.org/10.1016/j.jamcollsurg.2012.02.017.

76. Giurgius M., Bendure L., Davenport D.L., Roth J.S. The endoscopic component separation technique for hernia repair results in reduced morbidity compared to the open component separation technique. Hernia 2012; 16(1): 47-51, http://dx.doi. org/10.1007/s10029-011-0866-1.

77. Rulli F., Villa M., Tucci G. Endoscopic single-port "components separation technique" for postoperative abdominal reconstruction. J Minim Access Surg 2012; 8(2): 62-64, http:// dx.doi.org/10.4103/0972-9941.95541.

78. Vu T., Habib F. Utility of ultrasound in locating the linea 
semilunaris in the endoscopic component separation technique in ventral hernia repair. Ann R Coll Surg Engl 2011; 93(7): 553, http://dx.doi.org/10.1308/rcsann.2011.93.7.553a.

79. Hamad A., Marimuthu K., Mothe B., Hanafy M. Repair of massive inguinal hernia with loss of abdominal domain using laparoscopic component separation technique. J Surg Case Rep 2013; 2013(3): rjt008, http://dx.doi.org/10.1093/jscr/rjt008.

80. Botezatu A.A. Rezul'taty lecheniya retsidivnykh sredinnykh gryzh zhivota. V kn.: Materialy IX nauchnoy konferentsii "Aktual'nye voprosy gerniologii" [Treatment results of recurrent median abdominal hernias. In: Materials of IX scientific conference "Urgent problems of herniology"]. Moscow; 2012; p. 47-49.

81. Materialy IX nauchnoy konferentsii "Aktual'nye voprosy gerniologil". Interaktivnyy opros [Materials of IX scientific conference "Urgent problems of herniology". Interactive survey]. Moscow; 2012. URL: http://herniaweb.ru/index.php?cat_id=57.

82. Criss C.N., Petro C.C., Krpata D.M., Seafler C.M., Lai N., Fiutem J., Novitsky Y.W., Rosen M.J. Functional abdominal wall reconstruction improves core physiology and quality-oflife. Surgery 2014; 156(1): 176-182, http://dx.doi.org/10.1016/ j.surg.2014.04.010.

83. Pauli E.M., Rosen M.J. Open ventral hernia repair with component separation. Surg Clin North Am 2013; 93(5): 11111133, http://dx.doi.org/10.1016/j.suc.2013.06.010.

84. Hicks C.W., Krpata D.M., Blatnik J.A., Novitsky Y.W., Rosen M.J. Long-term effect on donor sites after components separation: a radiographic analysis. Plast Reconstr Surg 2012; 130(2): 354-359, http://dx.doi.org/10.1097/ PRS.0b013e3182589d79.

85. De Silva G.S., Krpata D.M., Hicks C.W., Criss C.N., Gao Y., Rosen M.J., Novitsky Y.W. Comparative radiographic analysis of changes in the abdominal wall musculature morphology after open posterior component separation or bridging laparoscopic ventral hernia repair. J Am Coll Surg 2014; 218(3): 353-357, http://dx.doi.org/10.1016/j.jamcollsurg. 2013.11.014.

86. Krpata D.M., Blatnik J.A., Novitsky Y.W., Rosen M.J. Posterior and open anterior components separations: a comparative analysis. Am J Surg 2012; 203(3): 318-322, http:// dx.doi.org/10.1016/j.amjsurg.2011.10.009.

87. Ross S.W., Oommen B., Heniford B.T., Augenstein V.A. Components separation in complex ventral hernia repair: surgical technique and post-operative outcomes. Surg Technol Int 2014; 24: 167-177.

88. Nazar'yants Yu.A., Vinnik Yu.S., Petrushko S.I., Miller S.V. Sposob kombinirovannoy plastiki bol'shikh posleoperatsionnykh ventral'nykh gryzh [A combined repair technique of large incisional ventral hernias]. Patent RF 2391052. 2010.

89. Vinnik Yu.S., Nazar'yants Yu.A., Petrushko S.I., Gorbunov N.S., Miller S.V. Sposob khirurgicheskogo lecheniya posleoperatsionnykh gryzh zhivota [Surgical technique for the treatment of incisional abdominal hernias]. Patent RF 2391924. 2010.

90. Vinnik Yu.S., Nazar'yants Yu.A., Petrushko S.I., Gorbunov N.S., Miller S.V. Sposob kombinirovannoy plastiki gigantskikh posleoperatsionnykh gryzh zhivota [A combined repair technique of giant incisional abdominal hernias]. Patent RF 2405494. 2010.

91. Malik A., Macdonald A.D., de Beaux A.C., Tulloh B.R. The peritoneal flap hernioplasty for repair of large ventral and incisional hernias. Hernia 2014; 18(1): 39-45, http://dx.doi. org/10.1007/s10029-013-1086-7.

92. Ng N., Wampler M., Palladino H., Agullo F., Davis B.R.
Outcomes of laparoscopic versus open fascial component separation for complex ventral hernia repair. Am Surg 2015; 81(7): 714-719.

93. Harth K.C., Rose J., Delaney C.P., Blatnik J.A., Halaweish I., Rosen M.J. Open versus endoscopic component separation: a cost comparison. Surg Endosc 2011; 25(9): 28652870, http://dx.doi.org/10.1007/s00464-010-1526-8.

94. Moazzez A., Mason R.J., Katkhouda N. A new technique for minimally invasive abdominal wall reconstruction of complex incisional hernias: totally laparoscopic component separation and incisional hernia repair. Surg Technol Int 2010; 20: 185-191.

95. Moazzez A., Mason R.J., Darehzereshki A., Katkhouda N. Totally laparoscopic abdominal wall reconstruction: lessons learned and results of a short-term follow-up. Hernia 2013; 17(5): 633-638, http://dx.doi.org/10.1007/s10029-0131145-0.

96. Klima D.A., Tsirline V.B., Belyansky I., Dacey K.T., Lincourt A.E., Kercher K.W., Heniford B.T. Quality of life following component separation versus standard open ventral hernia repair for large hernias. Surg Innov 2014; 21(2): 147-154, http://dx.doi.org/10.1177/1553350613495113.

97. Zielinski M.D., Goussous N., Schiller H.J., Jenkins D. Chemical components separation with botulinum toxin $A$ : a novel technique to improve primary fascial closure rates of the open abdomen. Hernia 2013; 17(1): 101-107, http://dx.doi. org/10.1007/s10029-012-0995-1.

98. Booth J.H., Garvey P.B., Baumann D.P., Selber J.C., Nguyen A.T., Clemens M.W., Liu J., Butler C.E. Primary fascial closure with mesh reinforcement is superior to bridged mesh repair for abdominal wall reconstruction. J Am Coll Surg 2013; 217(6): 999-1009, http://dx.doi.org/10.1016/j.jamcollsurg.2013. 08.015 .

99. Rawstorne E., Smart C.J., Fallis S.A., Suggett N. Component separation in abdominal trauma. J Surg Case Rep 2014; 2014(1): rjt133, http://dx.doi.org/10.1093/jscr/rjt133.

100. Löpez-Cano M., Pereira J.A., Armengol-Carrasco M. "Acute postoperative open abdominal wall": nosological concept and treatment implications. World $J$ Gastrointest Surg 2013; 5(12): 314-320, http://dx.doi.org/10.4240/wjgs. v5.i12.314.

101. Slater N.J., Knaapen L., Bökkerink W.J., Biemans M.J., Buyne O.R., Ulrich D.J., Bleichrodt R.P., van Goor H. Large contaminated ventral hernia repair using component separation technique with synthetic mesh. Plast Reconstr Surg 2015; 136(6): 796e-805e, http://dx.doi. org/10.1097/PRS.0000000000001793.

102. Rosen M.J., Jin J., McGee M.F., Williams C., Marks J., Ponsky J.L. Laparoscopic component separation in the singlestage treatment of infected abdominal wall prosthetic removal. Hernia 2007; 11(5): 435-440, http://dx.doi.org/10.1007/s10029007-0255-y.

103. Yegiyants S., Tam M., Lee D.J., Abbas M.A. Outcome of components separation for contaminated complex abdominal wall defects. Hernia 2012; 16(1): 41-45, http://dx.doi. org/10.1007/s10029-011-0857-2.

104. Ross S.W., Oommen B., Huntington C., Walters A.L., Lincourt A.E., Kercher K.W., Augenstein V.A., Heniford B.T. National outcomes for open ventral hernia repair techniques in complex abdominal wall reconstruction. Am Surg 2015; 81(8): 778-785.

105. Franklin B.R., Patel K.M., Nahabedian M.Y., Baldassari L.E., Cohen E.I., Bhanot P. Predicting abdominal 
closure after component separation for complex ventral hernias: maximizing the use of preoperative computed tomography. Ann Plast Surg 2013; 71(3): 261-265, http://dx.doi.org/10.1097/ SAP.0b013e3182773915.

106. Christy M.R., Apostolides J., Rodriguez E.D., Manson P.N., Gens D., Scalea T. The component separation index: a standardized biometric identity in abdominal wall reconstruction. Eplasty 2012; 12: e17.

107. Berger D., Lux A. Operative therapy of secondary ventral hernia: technical principles. Chirurg 2013; 84(11): 10011012, http://dx.doi.org/10.1007/s00104-011-2245-y.

108. Adekunle S., Pantelides N.M., Hall N.R., Praseedom R., Malata C.M. Indications and outcomes of the components separation technique in the repair of complex abdominal wall hernias: experience from the Cambridge plastic surgery department. Eplasty 2013; 13: e47.

109. Leppäniemi A., Tukiainen E. Reconstruction of complex abdominal wall defects. Scand J Surg 2013; 102(1): 14-19, http://dx.doi.org/10.1177/145749691310200104.

110. Morris L.M., LeBlanc K.A. Components separation technique utilizing an intraperitoneal biologic and an onlay lightweight polypropylene mesh: "a sandwich technique". Hernia 2013; 17(1): 45-51, http://dx.doi.org/10.1007/s10029012-0949-7.

111. Espinosa-de-los-Monteros A., Domínguez I., ZamoraValdés D., Castillo T., Fernández-Díaz O.F., Luna-Torres H.A. Closure of midline contaminated and recurrent incisional hernias with components separation technique reinforced with plication of the rectus muscles. Hernia 2013; 17(1): 75-79, http://dx.doi. org/10.1007/s10029-012-1012-4.

112. Roth J.S., Brathwaite C., Hacker K., Fisher K., King J. Complex ventral hernia repair with a human acellular dermal matrix. Hernia 2015; 19(2): 247-252, http://dx.doi.org/10.1007/ s10029-014-1245-5. 